\title{
Hydrocracking of Non-edible Vegetable Oils with Co-Ni/HZSM-5 Catalyst to Gasoil Containing Aromatics
}

\author{
Danawati Hari Prajitno*, Achmad Roesyadi, Muhammad Al-Muttaqii, Lenny Marlinda
}

Chemical Reaction Engineering Laboratory, Department of Chemical Engineering, Faculty of Industrial Technology, Sepuluh Nopember Institute of Technology, Sukolilo, Surabaya, 60111, Indonesia

Received: 21st November 2016; Revised: $9^{\text {th }}$ May 2017; Accepted: $20^{\text {th }}$ May 2017; Available online: 27th October 2017; Published regularly: December 2017

\begin{abstract}
Biofuel has been considered as one of the environmentally friendly energy sources to substitute fossil fuel derived from non-edible vegetable oil. This research aims to investigate the effect of the non-edible vegetable oil composition on a specific hydrocarbons distribution contained in biofuel and the aromatics formation through hydrocracking reaction with the Co-Ni/HZSM- 5 catalyst. The formation of aromatics from non-edible vegetable oils, such as: Cerbera manghas, rubber seed, and sunan candlenut oils, containing saturated, mono- and polyunsaturated fatty acids is presented. The hydrocracking reaction was carried out in a pressure batch reactor, a reaction temperature of $350{ }^{\circ} \mathrm{C}$ for $2 \mathrm{~h}$, reactor pressure of 15 bar after flowing $\mathrm{H}_{2}$ for 1 hour, and a catalyst/oil ratio of $1 \mathrm{~g} / 200 \mathrm{~mL}$. Liquid hydrocarbon product was analyzed by gas chromatography-mass spectrometry. Based on the GC-MS analysis, hydrocracking on three different oils indicated that polyunsaturated fatty acids were required to produce relatively high aromatics content. The sunan candlenut oil can be converted to gasoil range hydrocarbons containing a small amount of aromatic through hydrocracking reaction. Meanwhile, the aromatics in liquid product from hydrocracking of Cerbera manghas and rubber seed oils were not found. Copyright (C) 2017 BCREC Group. All rights reserved.
\end{abstract}

Keywords: Gasoil; Aromatic; Co-Ni/HZSM-5 catalyst; Non-edible vegetable oil; Hydrocracking

How to Cite: Prajitno, D.H., Roesyadi, A., Al-Muttaqii, M., Marlinda, L. (2017). Hydrocracking of Nonedible Vegetable Oils with Co-Ni/HZSM-5 Catalyst to Gasoil Containing Aromatics. Bulletin of Chemical Reaction Engineering \& Catalysis, 12 (3): 318-328 (doi:10.9767/bcrec.12.3.799.318-328)

Permalink/DOI: https://doi.org/10.9767/bcrec.12.3.799.318-328

\section{Introduction}

The high level of energy consumption in transportation causes a problem about high exhaust emissions, namely $\mathrm{CO}_{2}$ and $\mathrm{SO}_{2}$ in the air. One of the consequences of financing, in order to minimize $\mathrm{CO}_{2}$ levels, are seeking renewable energy sources without $\mathrm{CO}_{2}$ emissions. Biofuel produced by hydrocracking of non-edible

* Corresponding Author.

E-mail: dana@chem-eng.its.ac.id (Prajitno, D.H.)

Telp.: +62-31-5937968; Fax.: +62-31-5965183 vegetable oils has been considered as one of the most promising energies derived from renewable resources. Non-edible vegetable oils are a potential feedstock for production of biofuel because they contain fatty acids in carbon range from $\mathrm{C}_{14}-\mathrm{C}_{20}$ and relatively little oxygen that can be removed by hydrocracking [1]. The use of non-edible plant oils can be considered because they don't compete with the use of them as a food source [2]. In addition, non-edible oil has a higher yield than the edible oil so that the cost of production can be reduced. As reported by Gui et al. [3], the cost of raw materials reaches 
$70-80 \%$ of the total production cost of biodiesel production.

A liquid product produced through hydrocracking of vegetable oil contained specific hydrocarbon compounds, such as: n-paraffins, isoparaffins, cycloparaffins, and aromatics. In addition, the other side compounds, such as: olefins and oxygenated compounds including carboxylic acids, esters, acids, aldehydes, ketones, and alcohols, were also found in the liquid product. As explained in a previous study [4], the diesel range hydrocarbon was produced by deoxygenation of the refined soybean oil at temperature of $400^{\circ} \mathrm{C}$ and $9.2 \mathrm{MPa}$ of hydrogen with a sulfided $\mathrm{NiMoS}_{\mathrm{x}}$ catalyst contained aromatics of 3.2 area\% $\left(\mathrm{C}_{17}-\mathrm{C}_{18}\right)$. Cobalt and molybdenum catalysts were used by Pinto et al. [5] in the hydrogenation of rapeseed oil to produce a high content of aromatics about $50 \%$ at a temperature of $400{ }^{\circ} \mathrm{C}$ and an initial hydrogen pressure of $1.10 \mathrm{MPa}$ for $3 \mathrm{~h}$. Verma et al. [6] reported that hydrocracking of jatropha oil with sulphided NiMo and NiW catalysts supported on hierarchical mesoporous SAPO-11 produced kerosene range hydrocarbons containing 8 vol.\% of desired aromatic. Marlinda et al. [7] also reported that pentadecane and heptadecane were the main abundant hydrocarbon compounds in gasoil-range hydrocarbon produced in hydrocracking of Cerbera manghas oil at a temperature of $350{ }^{\circ} \mathrm{C}, 15$ bar for $2 \mathrm{~h}$ with $\mathrm{Co}(0.88 \%)-\mathrm{Ni}(3.92 \%) / \mathrm{HZSM}-5$ catalyst. The authors also reported that 2.9 area\% of aromatics $\left(\mathrm{C}_{11}-\mathrm{C}_{12}\right)$ were found in this condition. In addition, Al-Muttaqii et al. [8] reported that aromatics of 10.52 area\% $\left(\mathrm{C}_{11}-\mathrm{C}_{17}\right)$ were found in the liquid product produced through hydrocracking of the sunan candlenut oil at a temperature of $350{ }^{\circ} \mathrm{C}, 15$ bar for $2 \mathrm{~h}$ with $\mathrm{Co}-\mathrm{Ni} /$ HZSM-5 catalyst. As reported by a previous study [6], the aromatic production during the hydroprocessing of vegetable oil can reduce the process cost. The aromatization reaction caused the decrease of hydrogen consumed during hydrocracking, so that this process gave a considerable benefit [6]. The suitable aromatic hydrocarbons can improve the properties of transport fuel [9]. Rabaev et al. [1] also reported that a diesel containing a certain amount of aromatics are needed and aromatics below $8 \%$ contained jet fuel may cause dragging of contraction seals. However, according to Santillan-Jimenez et al. [9], the aromatization is an undesirable side reaction so that it is necessary to control this reaction during hydrocracking of vegetable oil. Biofuel containing aromatic compounds was assumed to be produced through the nine interconnected reactions of triglyceride molecules and intermediate, i.e. dehydrogenation of cyclohexene to aromatic [1].

The other some research papers studied preparation of catalysts by incipient wetness impregnation and its application in hydrocracking of vegetable oils in the presence of a nickel-based catalyst to produce a paraffin-rich mixture of hydrocarbons in the range of $\mathrm{C}_{14}$ $\mathrm{C}_{20}$. The hydrocarbon compounds founded in the liquid product were similar to petroleum diesel as detected by GCMS chromatogram in Figure 1. When the $\mathrm{Ni}$ or $\mathrm{Pd}$ supported on $\gamma$ $\mathrm{Al}_{2} \mathrm{O}_{3}$ catalysts were used in hydroprocessing of

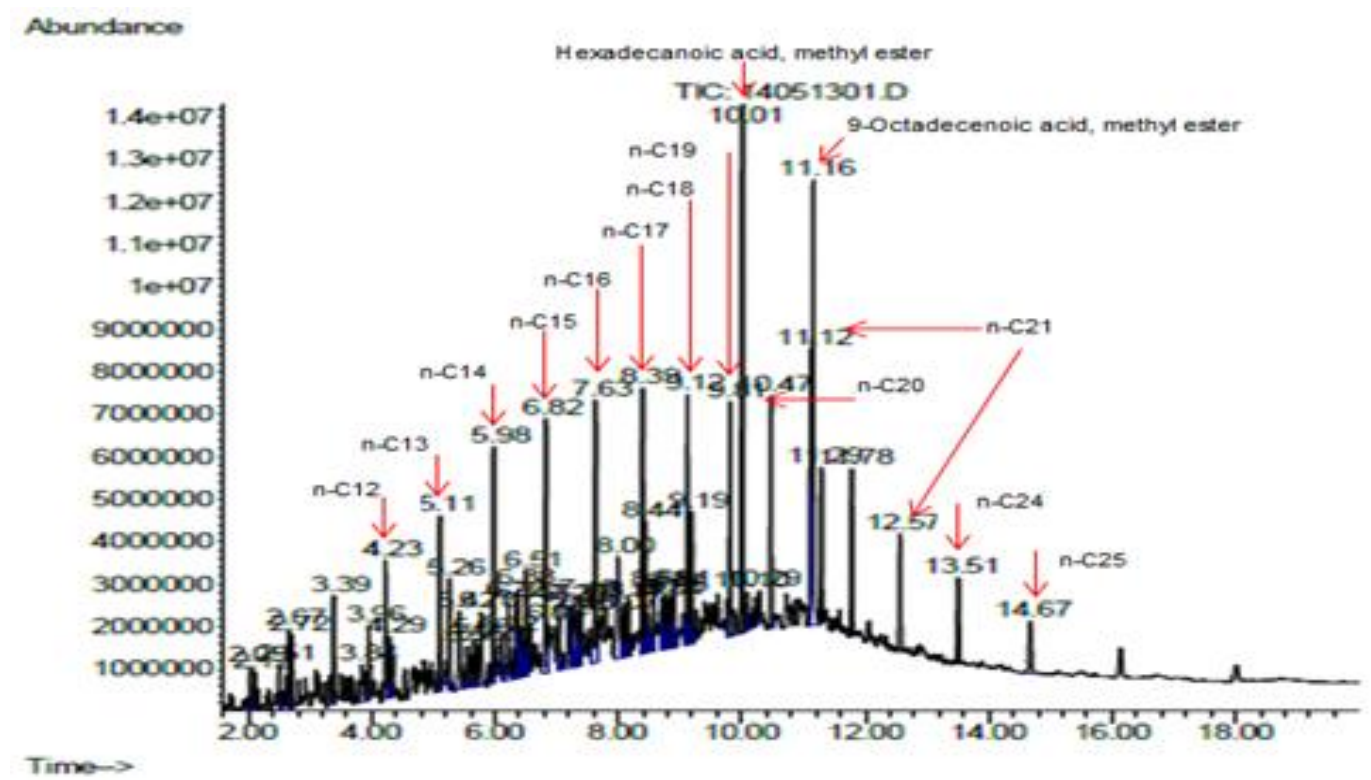

Figure 1. GC-MS Chromatogram of the commercial petroleum diesel [14] 
soybean oil, the pentadecane and heptadecane as the main abundant hydrocarbon compounds in gasoil-like hydrocarbon were produced [10]. In addition, Satyarthi et al. [11] obtained octadecane $\left(\mathrm{C}_{18}\right)$ as the main hydrocarbon product through deoxygenation of $\mathrm{C}_{18}$ fatty acid during hydroprocessing of soybean oil with $\mathrm{Ni}-\mathrm{Mo} / \gamma-\mathrm{Al}_{2} \mathrm{O}_{3}$ catalyst. Hydrocarbons (primarily $\mathrm{n}-\mathrm{C}_{15}$ to $\mathrm{n}-\mathrm{C}_{18}$ alkanes) were produced by hydrocracking of jatropha oil with $\mathrm{Ni}$ $\mathrm{HPW} / \mathrm{Al}_{2} \mathrm{O}_{3}$ as a new green catalyst, as found by Liu et al. [12]. Marlinda et al. [13] also found the effect of varying nickel and cobalt content supported on HZSM-5 catalyst on product distribution produced by hydrocracking of Cerbera manghas oil and it was implied that the formation of straight chain hydrocarbons $\left(\mathrm{C}_{12}-\mathrm{C}_{20}\right)$ increased through decarboxylation and/or decarbonylation reaction during hydrocracking process.

Non-edible vegetable oils, such as: Cerbera manghas, rubber seed, sunan candlenut and Calophyllum inophyllum oil, are recommended as a potential biofeed for biofuel productions via hydrocracking $[2,7,8,13,14]$. Therefore, it is suggested that the fatty acid composition of vegetable oil affects on hydrocarbon product distribution $[1,6]$ corresponding to the properties of biofuel [3]. It is interesting to investigate the effects of the non-edible vegetable oil composition on a specific hydrocarbons distribution contained in the biofuel and the aromatics formation. A mild hydrocracking of these nonedible vegetable oils containing saturated, mono- and poly-unsaturated fatty acids with the Co-Ni/HZSM-5 catalyst in a batch pressure reactor were performed to study the aromatics formation.

\section{Materials and Methods}

\subsection{Non-edible vegetable oil as biofeed}

Rubber, sunan candlenut, and Cerbera manghas seeds were extracted with screw press machine in Balittas, Malang, Indonesia.
Rubber seeds were collected from rubber plants that grow in Jember, East Java, Indonesia. Meanwhile, the Cerbera manghas plants were found as the greening plant in Surabaya, East Java, Indonesia, and the sunan candlenut seeds were obtained from fruits which were collected from Bogor, West Java, Indonesia. All vegetable oils used in this work were grouped in non-edible oil plants. Their advantages are ease of growing in marginal land, they do not competitive with a food supply because of the presence of toxic compound, feedstock supply can be kept sustainability, high oil content and oil consist of fatty acids in chain length $\mathrm{C}_{18}$ with double bonds in triglycerides. The sunan candlenut oil contained more eleostearic acid (C18:3) indicating the presence of toxic compound, while the Cerbera manghas oil contained cerberin as a toxic compound.

Rubber seed, sunan candlenut, and Cerbera manghas oils were analyzed by gas chromatography-mass spectrometry. The analysis results are presented in Table 1 indicating that the sunan candlenut and the rubber seed oils are composed of a high content of polyunsaturated fatty acid, while the Cerbera manghas oil contains highly mono-unsaturated fatty acids. The detailed fatty acid composition of the sunan candlenut and the Cerbera manghas oil used in this work were reported by the previous study $[8,13]$.

\subsection{Preparation of catalyst}

The HZSM-5 catalyst was obtained from calcination of a commercial NH $\mathrm{NH}_{4}$-ZSM-5 (Zeolyst International Inc.). HZSM-5 catalyst used as a support in this work has been prepared by a procedure in the previous study and its detailed characterization showed specific peaks of ZSM located at $2 \theta=7-8^{\circ}$ and $22-24^{\circ}$ was published elsewhere [8]. Furthermore, the zeolite was impregnated with $\mathrm{Ni}\left(\mathrm{NO}_{3}\right)_{2} .6 \mathrm{H}_{2} \mathrm{O}$ (Merck, $\geq 98 \%$ ) and $\mathrm{Co}\left(\mathrm{NO}_{3}\right)_{2} .6 \mathrm{H}_{2} \mathrm{O}$ (Merck, $\geq 98$ $\%$ ), keeping metal loading of $5 \%$ and a weight

Table 1. Non-edible vegetable oil fatty acid composition

\begin{tabular}{lccc}
\hline Properties & $\begin{array}{c}\text { Rubber } \\
\text { seed }^{*}\end{array}$ & $\begin{array}{c}\text { Sunan } \\
\text { candlenut }^{*}[8]\end{array}$ & $\begin{array}{c}\text { Cerbera manghas* } \\
{[13]}\end{array}$ \\
\hline $\begin{array}{l}\text { Degree of saturation } \\
\text { Saturated fatty acid (palmitic and stearic) }\end{array}$ & 3.67 & - & - \\
Mono-unsaturated fatty acids (oleic) & - & - & abundant \\
Poly-unsaturated fatty acid (linoleic and linolenic) & 95.2 & abundant & - \\
\hline Density, $\mathrm{g} / \mathrm{cm}^{3}$ & 0.8889 & 0.8971 & 0.8810 \\
\hline
\end{tabular}

*area $\%$ 
metal ratio of 1:2 for cobalt-nickel. With the incipient wetness impregnation procedure in a previous study [7], the Co-Ni/HZSM-5 catalyst was obtained.

\subsection{Catalyst characterization}

X-ray diffraction (XRD) was used to measure phase analysis and the crystallinity of CoNi/HZSM-5 catalyst. XRD diffraction patterns of the catalyst were recorded on $2 \theta$ of $10-90^{\circ}$ using a PANalytical X'Pert PRO X-ray diffractometer with a $\mathrm{Cu}-\mathrm{Ka}$ radiation source operating at $40 \mathrm{kV}$ and $30 \mathrm{~mA}$. Quantachrome NovaWin Version 11.03 instrument was applied to determine the surface area and pore volume of the catalyst through Brunauer-Emmett-Teller (BET) and Barrett-Joyner-Halenda (BJH) methods. SEM instrument (Inspect S50, FEI Company) was used to study the surface morphology of Co-Ni/HZSM-5 catalyst. EDAX was performed to determine $\mathrm{Si} / \mathrm{Al}$ ratio and cobaltnickel content.

\subsection{Hydrocracking and analytical proce- dure}

In this work, the equipment and procedure of hydrocracking were given elsewhere [13]. The catalyst of $1 \mathrm{~g}$ was placed in the reactor and followed non-edible vegetable oil of 200 $\mathrm{mL}$. A temperature of $350{ }^{\circ} \mathrm{C}$ for $2 \mathrm{~h}$ were operation condition in the reactor. After $2 \mathrm{~h}$, liquid product was produced. Gas chromatography-mass spectrometry was used to identify hydrocarbon in the liquid product. Standard GC used was Agilent HP 6890 models 19091S-433, HP-5MS capillary column $30 \mathrm{~m} \times 250 \mu \mathrm{m} \times$
$0.25 \mu \mathrm{m}$, at a nominal initial pressure of 13.3 psi, the oven temperature of $150{ }^{\circ} \mathrm{C}$ for $2 \mathrm{~min}$, then increased to $240{ }^{\circ} \mathrm{C}$ at $10{ }^{\circ} \mathrm{C} / \mathrm{min}$ for 11 min. All hydrocarbon components were identified using the Wiley275 and NIST02 mass spectral library of data. The hydrocarbon components with a probability match equal to or higher than $80 \%$ were considered. Then, hydrocarbon $\left(\mathrm{C}_{15}-\mathrm{C}_{22}\right)$ in the liquid product were listed as gasoil-range hydrocarbon.

\section{Results and Discussion}

\subsection{Catalyst characterization}

The XRD patterns of Co-Ni/HZSM-5 catalyst are shown in Figure 2. Small peak intensity showed the existence of $\mathrm{Co}_{3} \mathrm{O}_{4}$ crystallites. In addition, diffraction peaks were located at $2 \theta$ of $34.3^{\circ}$, which was attributed to the existence of CoO. Nickel was detected at $2 \theta$ of $51.8^{\circ}$. The catalyst has a framework of the MFI structure as the only crystalline phase [15]. According to a previous study [8], the metal impregnated HZSM-5 catalyst had still a structure similar to HZSM-5. The result of EDAX measurement also proved the existence of cobalt and nickel in HZSM-5. Figure 3 indicates that $\mathrm{Co}$ and $\mathrm{Ni}$ were found in the HZSM-5 pores. The actual metal content on support was 2.15 wt.\% of Co and 4.7 wt.\% of Ni. The metal content obtained was approximately 5 wt.\% with Co: Ni ratio of 1:2 for Co-Ni/HZSM-5 catalyst.

The surface area, average pore size, and pore volume of Co-Ni/HZSM-5 catalyst are listed in Table 2. The HZSM-5 had high surface area of $355.967 \mathrm{~m}^{2} / \mathrm{g}$ [8], while the impregna-

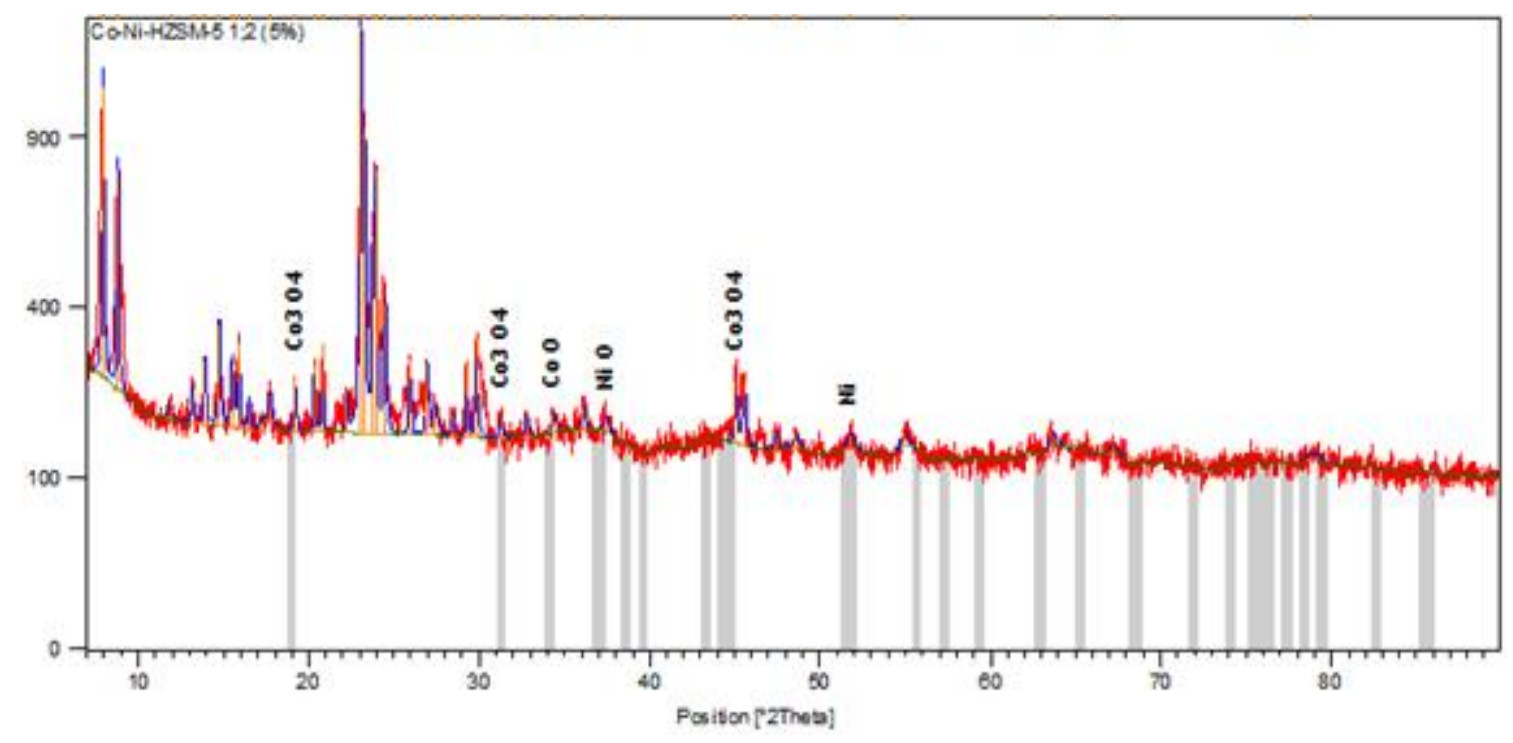

Figure 2. XRD patterns of Co-Ni/HZSM-5 catalyst 
tion of Co and Ni into the HZSM-5 pore caused the decrease of surface area and pore volume of Co-Ni/HZSM-5 catalyst. These changes indicated that the metal particles were successfully dispersed in surface area and HZSM-5 pore.

\subsection{Hydrocracking of non-edible vegetable oils}

\subsubsection{GC-MS analysis}

GC-MS chromatogram of rubber seed oil and liquid product produced are shown in
Figure 4. If Figure 4(a) and (b) are compared, the compounds with retention time of 14-22 min in the rubber seed oil disappear after hydrocracking reaction. According to Zheng et al. [16], triglycerides with long chain fatty acids were converted into short chain molecules by cracking, isomerization, cyclization, and aromatization reaction [16]. Figure 4(b) shows that the amounts of different hydrocarbon compounds with retention time of $0-12 \mathrm{~min}$ in liquid product increase after cracking reaction.

Table 2. Properties of catalyst

\begin{tabular}{ccccc}
\hline Catalyst & Si/Al (EDAX) & $\begin{array}{c}\text { BET surface area } \\
\left(\mathrm{m}^{2} / \mathrm{g}\right)\end{array}$ & $\begin{array}{c}\text { Average pore size } \\
(\mathrm{nm})\end{array}$ & $\begin{array}{c}\text { Pore volume } \\
\left(\mathrm{cm}^{3} / \mathrm{g}\right)\end{array}$ \\
\hline Co-Ni/HZSM-5 & 24.7 & 336.423 & 1.326 & 0.223 \\
\hline
\end{tabular}

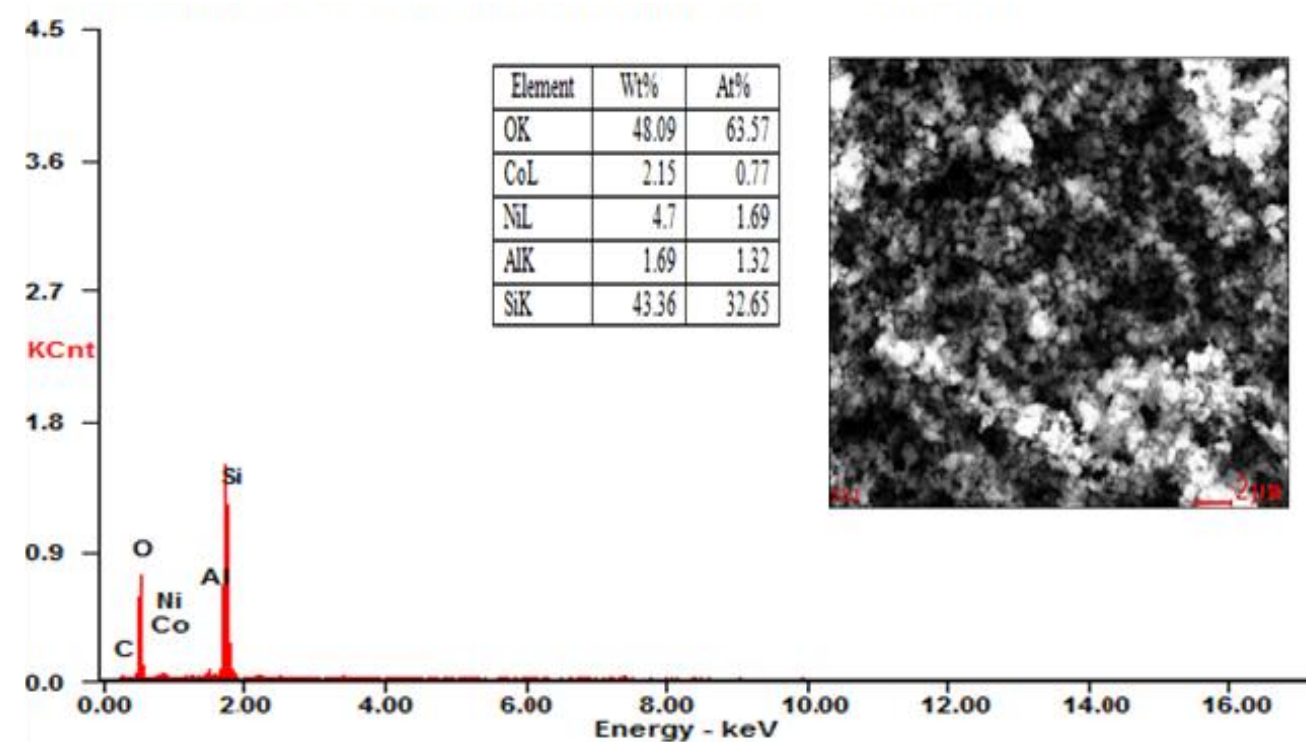

Figure 3. SEM-EDAX of Co-Ni/HZSM-5 catalyst
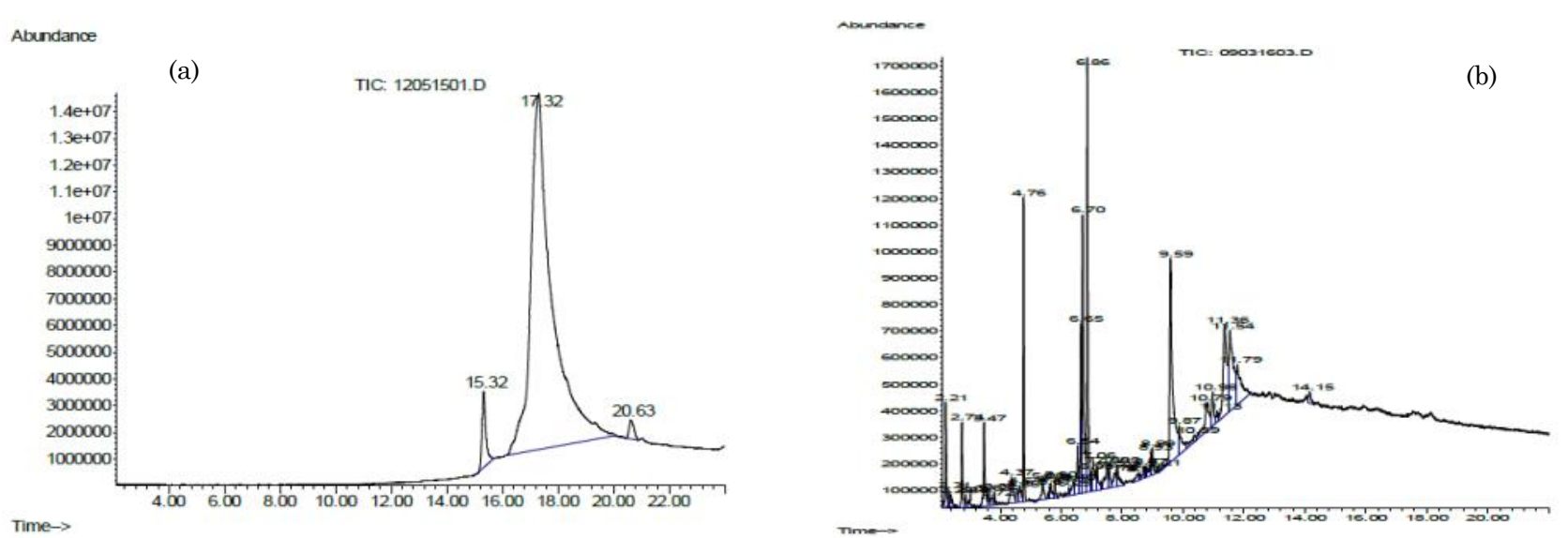

Figure 4. GC-MS Chromatogram of (a) rubber seed oil, (b) liquid product obtained from hydrocracking at $350{ }^{\circ} \mathrm{C}$ for $120 \mathrm{~min}$ with $\mathrm{Co}-\mathrm{Ni} / \mathrm{HZSM}-5$ catalyst, metals ratio of $1: 2$ 
Figure 5 shows n-paraffins produced from hydrocracking of rubber seed oil. The liquid product contains pentadecane of 5.35 area\%, heptadecane of 10.11 area\% and 46.36 area $\%$ of oxygenated compounds including carboxylic acids. The carboxylic acids found in liquid product were oleic acid of 20.86 area $\%$ and palmitic acid of 14.64 area\%. It suggested that in the first step hydroconversion reaction of rubber seed oil fatty acids produced the oxygenated compounds through a sequential mechanism as reported by García-Dávila et al. [17] who did the hydroconversion of Jatropha curcas $L$. oil. Therefore, the longer reaction time at the same condition was needed. In addition, the temperatures above $350{ }^{\circ} \mathrm{C}$ were also needed to crack $\mathrm{C}=\mathrm{O}$ bond through decarboxylation and/or decarbonylation. Aromatic was not found in liquid product, while a small amount of cyclotetracosane of 0.69 area\% and 4-ethylcyclohexene of 0.81 area\% were found in liquid product. The presence of cycloparaffins and/or cycloolefins suggested that various reactions occurred during hydrocracking process, including cyclization and dehydration. It was important to be observed that olefins of 12.96 area\% were also found in liquid product, i.e 8-heptadecene. According to Kim et al. [18], dehydrogenation and/or hydrogenolysis of $n$-alkanes can lead to olefin formation at a temperature of $350{ }^{\circ} \mathrm{C}$ when the Ni catalyst was used. Additionally, Katikaneni et al. [19] stated that aromatic hydrocarbons were produced through oligomerization, acid catalyzed cyclization and H-transfer reactions on hydrocarbon molecules.
Figure 6 shows that liquid product produced from hydrocracking of the sunan candlenut oil contained a high aromatic content in retention time range of 2.34-2.9 and 7.05-7.56. The hydrocarbon compound produced in this work had been listed and reported in the previous work [8]. The hydrocarbons correspond to peak spectra presented in Figure 6. In addition, peak spectra of saturated fatty acid, such as: palmitic acid and stearic acid, were also detected. It indicated that hydrogenation reaction has been well proceeded with helping cobalt dan nickel in form as a metal oxide crystal to saturate the double bonds of linoleic acid. As reported by a previous study [8], when CoNi/HZSM-5 catalyst was used in the same condition in this work, the hydrocracking of sunan candlenut oil produced a liquid product containing aromatic compounds in the form of abundant monocyclic aromatic hydrocarbons (MAHs), i.e. n-hexylbenzene, n-heptylbenzene, nonylbenzene, n-octylbenzene, and nundecylbenzene. Meanwhile, a cycloparaffin was found in the form of long branched chain cyclohexane, i.e. 1-(1,5-dimethylhexyl)-4-(4methyl pentyl) cyclohexane. The oxygenated compounds, including carboxylic acids of 58.89 area\%, were also found. It is important to be noted that olefin of 4.18 area\% was found in liquid product.

Figure 7 shows that liquid fuel of Cerbera manghas oil contained still many oxygenated compound including carboxylic acids, but the isoparaffin was found, i.e. 2,6,10,14tetramethyl hexadecane $\left(\mathrm{C}_{20} \mathrm{H}_{42}\right)$ of 1.64 area\%

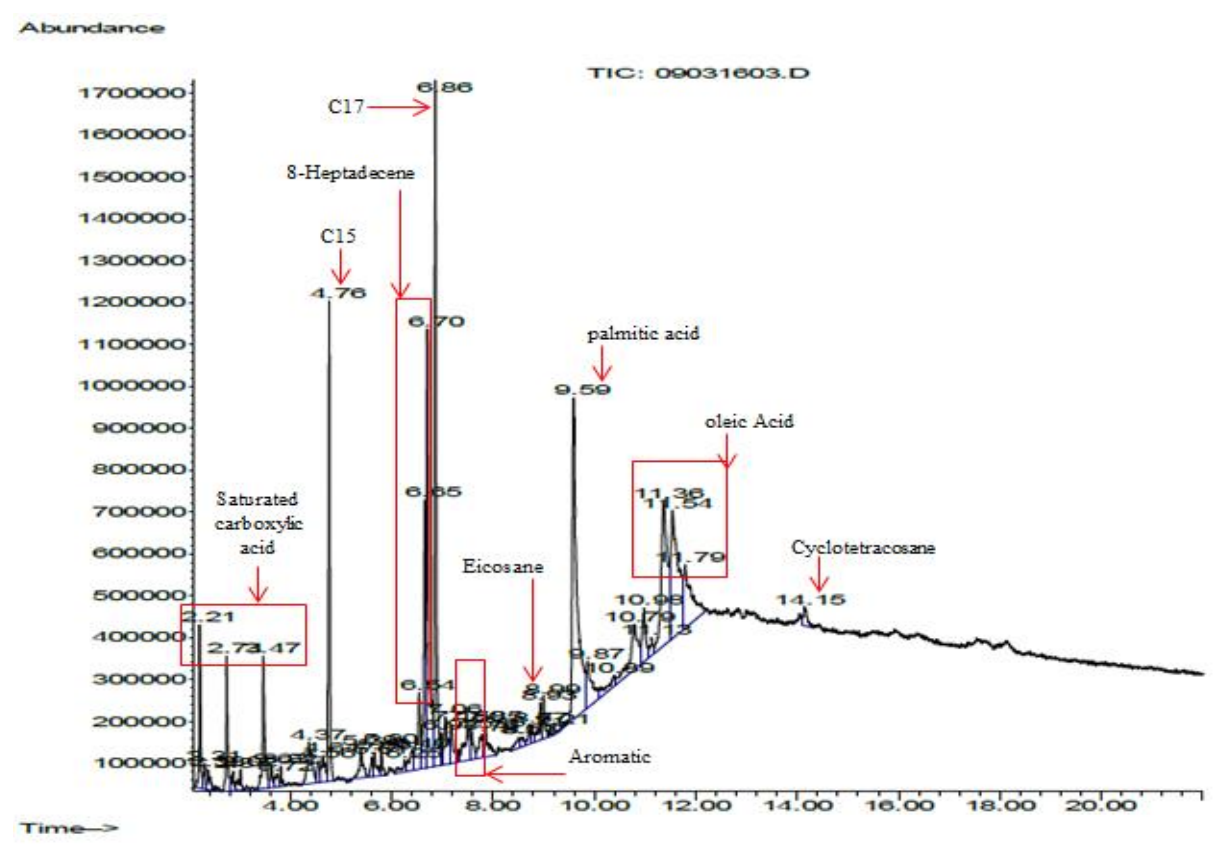

Figure 5. GCMS chromatogram of liquid product produced from hydrocracking of rubber seed oil 
(molecular weight of 282). Subsequently, liquid product containing pentadecane of 7.16 area\% and heptadecane of 6.20 area\%, was also detected. According to Hancsók et al. [20], the presence of isoparaffins can improve the properties of liquid product containing gasoil-range hydrocarbon which have a high cetane number and cold flow properties are good. Meanwhile, n-paraffin as abundant compound in liquid product can produce the clean combustion and these compounds can be biodegraded relatively easier than other hydrocarbons. Composition of liquid product consisted of hydrocarbons, i.e. 16.61 area\% of n-paraffins, 1.91 area\% of cycloparaffins, and aromatic, was not detected. It is interesting to study that the nonylcyclohexane
$\left(\mathrm{C}_{15} \mathrm{H}_{24}\right)$ corresponds to $\mathrm{n}$-paraffin formation, i.e. pentadecane. However, it was still found 55.81 area $\%$ of carboxylic acids. It is important to be noted that olefin of 14.9 area\% was also found in liquid product in the form of 8heptadecene. The carboxylic acid formed was dominated by saturated fatty acids, i.e. palmitic acid and in the small amount of capric acid. At the same process condition to this work, the previous study found that the gasoil $\left(\mathrm{C}_{12}-\mathrm{C}_{18}\right)$ was produced from hydrocracking of Cerbera manghas oil in the presence Co(0.88\%)-Ni(3.92\%)/HZSM-5 catalyst. The liquid product contained pentadecane of 20.06 area $\%$, heptadecane of 14.13 area $\%$, and oxygenated compounds of 9.51 area\%. A small

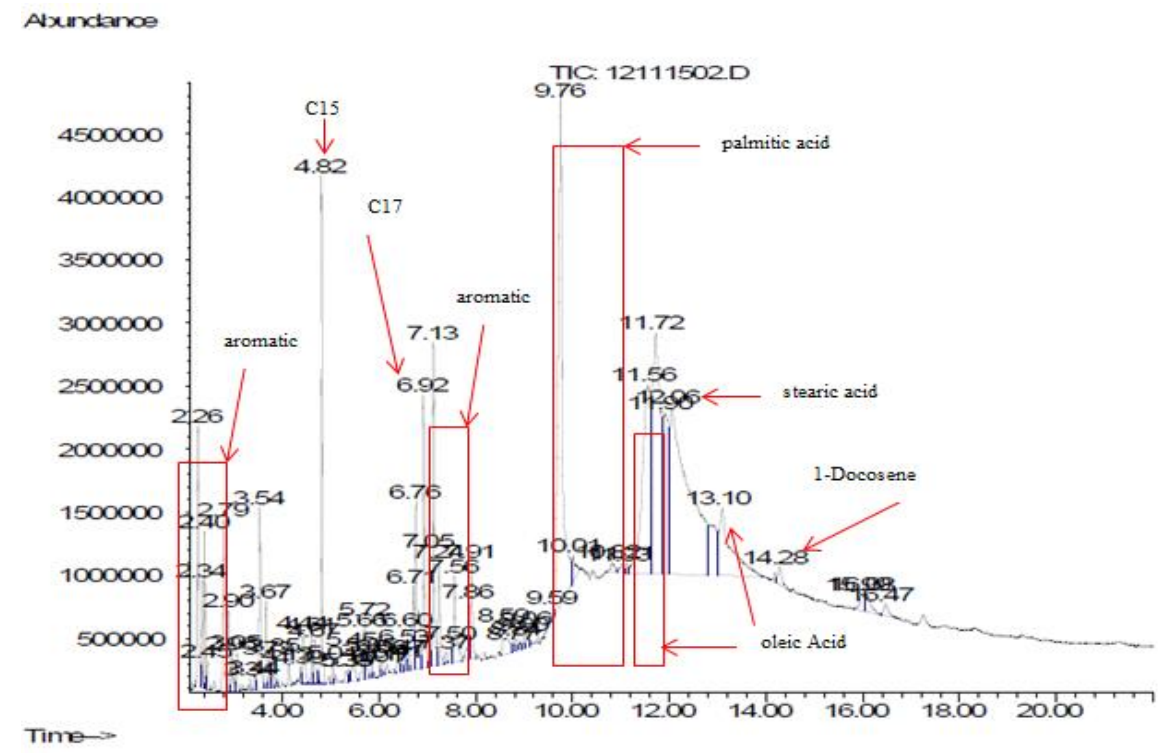

Figure 6. GC-MS chromatogram of liquid product produced from hydrocracking of sunan candlenut oil

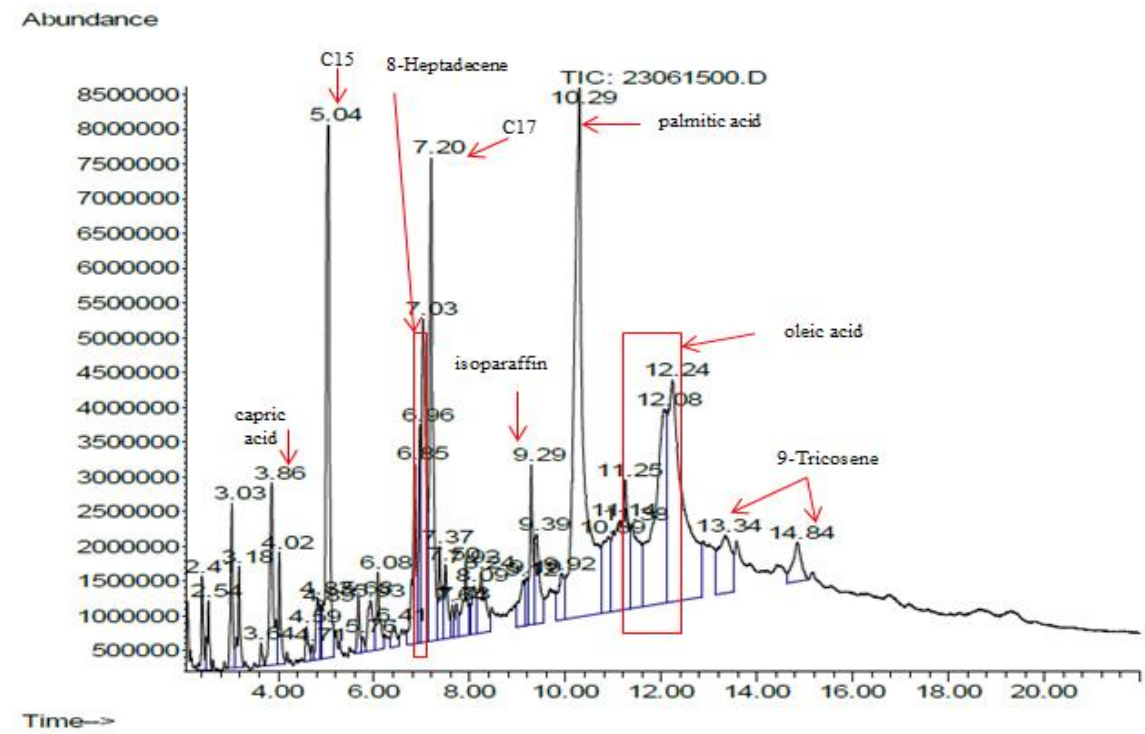

Figure 7. GC-MS chromatogram of liquid product produced from hydrocracking of Cerbera manghas 
amount of cycloparaffin (less than 5 area\% in total) were also observed in the form of long branched chain alkylcyclohexane. Diaromatic (less than 1 area\%) was found in the form of naphthalene, and olefin of 13.49 area\% was also observed [7].

According to the explanation and GC-MS chromatogram as presented in Figures 5, 6, and 7 , the oxygenated compounds were found in large amount quantities around more than $45 \%$. Therefore, to obtain hydrocarbon compounds, the reactor temperatures above $350{ }^{\circ} \mathrm{C}$ were needed for cracking process. Acidity sites also did play in the cracking reaction. In addition, the composition of different hydrocarbons found in liquid product showed that the metal ratio and loading impregnated on HZSM-5 pore affected cracking of $\mathrm{C}=\mathrm{O}, \mathrm{C}-\mathrm{C}$, and $\mathrm{O}-\mathrm{C}=\mathrm{O}$ bonds in oxygenated compounds. It can be stated that metal oxide affects hydrocarbon product distribution. When Figures 1, 5, 6, and 7 are compared, it implied that retention time of $\mathrm{n}-\mathrm{C}_{15}$ and $\mathrm{n}-\mathrm{C}_{17}$ in liquid product slightly shifted from the retention time of $\mathrm{C}_{15}$ and $\mathrm{n}-\mathrm{C}_{17}$ detected in a commercial petroleum diesel. The $\mathrm{n}-\mathrm{C}_{15}$ and $\mathrm{n}-\mathrm{C}_{17}$ in liquid product produced via hydrocracking of non-edible vegetable oil are located at the same retention time from 4.76 to 6.92 .

3.2.2 Influence of saturation degree of nonedible vegetable oil on paraffin, cycloparaffin and alkylbenzenes formation

Table 3 shows the comparison of hydrocarbon compounds of liquid product produced from hydrocracking of different non-edible vegetable oils at $350{ }^{\circ} \mathrm{C}$ using $\mathrm{Co}-\mathrm{Ni} / \mathrm{HZSM}-5$ catalyst. It suggested that the formation of $n$-paraffins increased with increasing the degree of saturation of non-edible vegetable oils. Meanwhile, cycloparaffins and alkylbenzenes increased with the increasing of the degree of unsaturation of non-edible vegetable oils. It was found that the sunan candlenut oil liquid product produced alkylbenzenes in range of gasoil (predominant $\mathrm{C}_{17}$ ). This result corresponded to the result obtained by Da Rocha Filho et al. [21] using the $\mathrm{NiMo} / \gamma-\mathrm{Al}_{2} \mathrm{O}_{3}$ catalyst on hydrocracking of soybean, maracuja, and buriti oils at a temperature of $360^{\circ} \mathrm{C}, 14 \mathrm{MPa}$ for $2 \mathrm{~h}$. According to this author, cyclization reaction and $\alpha$-, $\beta$-cleavages increased, because of the pres-

Table 3. The comparison of hydrocarbon compounds of liquid product produced from hydrocracking of different non-edible vegetable oils at $350{ }^{\circ} \mathrm{C}$ with $\mathrm{Co}-\mathrm{Ni} / \mathrm{HZSM}-5$ catalyst

\begin{tabular}{lcccccc}
\hline \multirow{2}{*}{$\begin{array}{c}\text { Non-edible } \\
\text { vegetable oil }\end{array}$} & \multicolumn{4}{c}{ Hydrocarbon compounds, area\% } & \multirow{2}{*}{ Ref. } \\
\cline { 2 - 5 } & paraffins & $\begin{array}{c}\text { Cyclo- } \\
\text { paraffins }\end{array}$ & $\begin{array}{c}\text { Alkyl- } \\
\text { benzenes }\end{array}$ & acids $^{\mathrm{f}}$ & otherg $^{\text {nannnnnn}}$ & \\
\hline Cerbera manghas & $18.25^{\mathrm{a}}$ & $1.91^{\mathrm{b}}$ & 0 & 55.81 & 14.9 & Present study \\
Rubber seed & $17.44^{\mathrm{a}}$ & $2.34^{\mathrm{c}}$ & 0 & 44.51 & 12.96 & Present study \\
Sunan candlenut & $6.87^{\mathrm{a}}$ & $12.29^{\mathrm{d}}$ & $10.52^{\mathrm{e}}$ & 35.03 & 4.18 & [8] \\
\hline
\end{tabular}

amainly paraffins, $\mathrm{n}-\mathrm{C}_{15}$ and $\mathrm{n}-\mathrm{C}_{17}$; ${ }^{\mathrm{b}}$ mainly cycloparaffin, molecular weight 210 ; ${ }^{\mathrm{c}}$ mainly cycloolefin, molecular weight 262 ; dmainly cycloparaffin, molecular weight 280 ; emainly alkylbenzenes, molecular weights $162,176,232$; fmainly fatty acids, i.e palmitic acid, stearic acid, oleic acid ; gothers = olefin

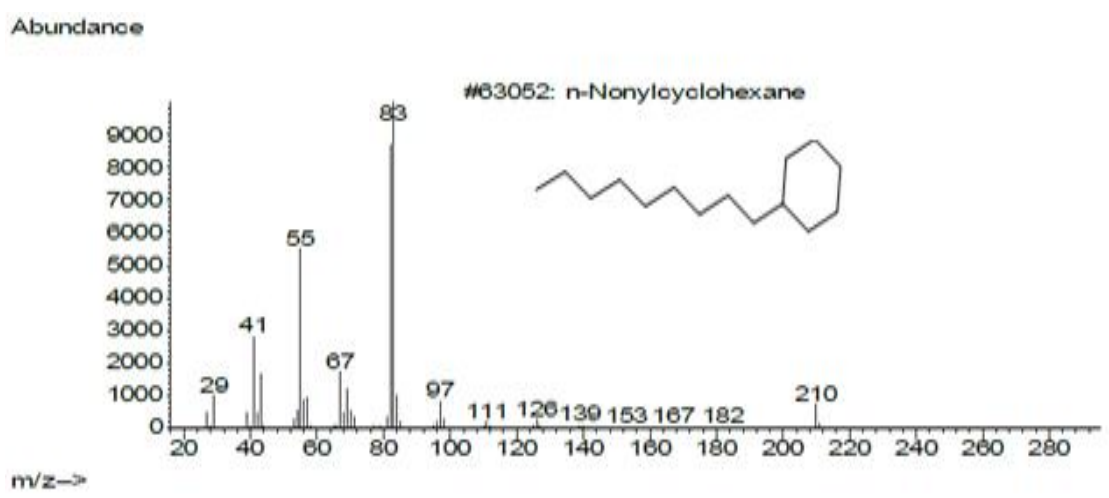

Figure 8. Mass spectra of cycloparaffin produced from hydrocracking of Cerbera manghas oil at a temperature of $350{ }^{\circ} \mathrm{C}$. 
ence of unsaturated bonds in vegetable oils. It can be observed that the different chemical structure of cyclic compounds was identified in liquid product produced in this work. Some mass spectra of cycloparaffins were presented in Figures 8, 9, and 10. A small amount of linear cycloparaffin (molecular weight 210, less than 1 area\%) was found in liquid product produced from hydrocracking of Cerbera manghas oil. Then, linear and branched cycloparaffin (molecular weight 280) was found in liquid product produced from hydrocracking of sunan candlenut oil. Finally, a small amount of linear and branched cyclohexene (molecular weight 262 , less than 1 area\%) was also identified in liquid product produced from hydrocracking of rubber seed oil. Although aromatic has not formed in hydrocracking of rubber seed oil at $350{ }^{\circ} \mathrm{C}$, the presence of cyclohexene compound is an indication that the formation of aromatic compounds will occur at temperatures above $350{ }^{\circ} \mathrm{C}$. According to Da Rocha Filho et al. [21], cyclohexene as intermediate state was formed because of the presence of two or three double bonds leading to form aromatic compound. While one double bond was only needed to form cycloparaffin compounds. Later, the both of compounds were converted to aromatic compounds.
According to the results, it suggested that the degree of saturation of non-edible vegetable oils affected the formation of aromatic compounds during hydrocracking. It was consistent with reported results $[1,21]$ using some different catalysts in hydrocracking of various vegetable oils. According to a previous study [22], the color of vegetable oil after catalytic cracking becomes darker because of the presence of polyaromatic hydrocarbons or large aromatics in the liquids. The polyaromatic hydrocarbons form coke giving a dark color. If it was observed on liquid product, it can be seen that sunan candlenut liquid product was darker than the others. It showed the presence of large aromatics in liquid product. It was consistent with the GC-MS analysis result. The produced liquid product was hydrogenated oil which had not been purified so that this liquid product can not be directly compared with standard fuel. The determining of hydrocarbon composition of the liquid product was the way chosen to imply that this liquid product has the similar hydrocarbon composition to the petroleum fuel. So far, according to the results above, hydrocracking of non-edible vegetable oils in this work has produced liquid hydrocarbon product or biofuel. Later physical properties, such as:

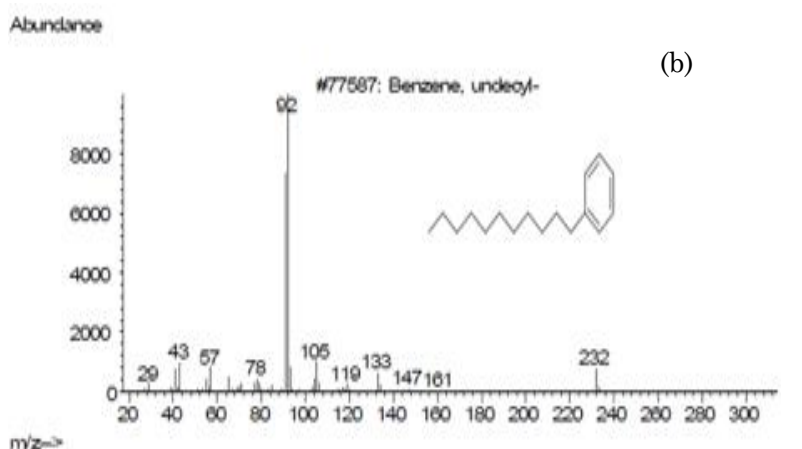
mvz-.:-

Abunclance

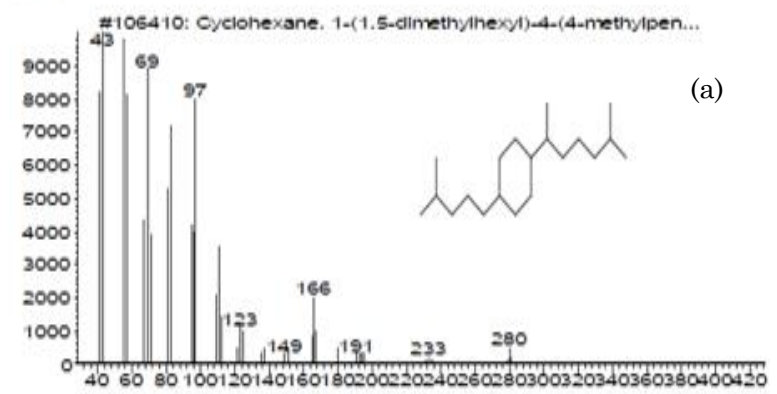

Figure 9. Mass spectra of cycloparaffin (a) and alkylbenzenes (b) produced from hydrocracking of sunan candlenut oil at a temperature of $350{ }^{\circ} \mathrm{C}$

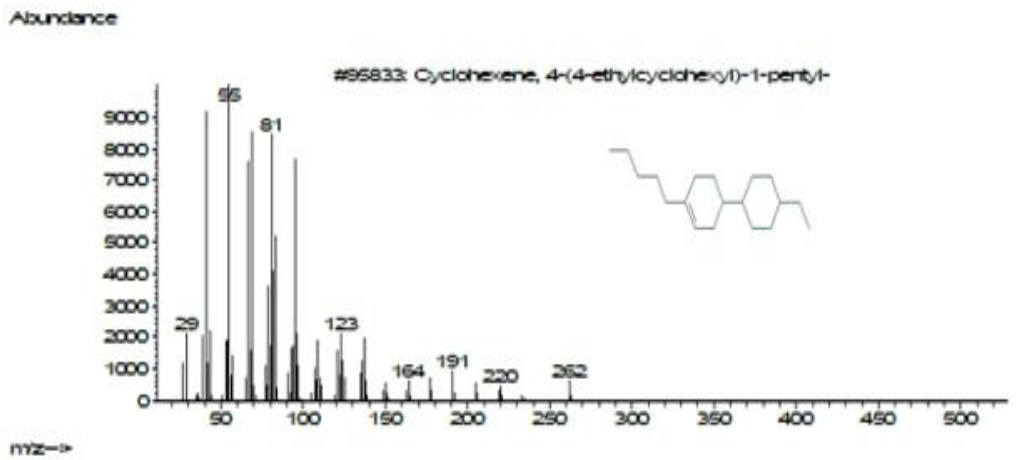

Figure 10. Mass spectra of cycloolefin produced from hydrocracking of rubber seed oil at a temperature of $350{ }^{\circ} \mathrm{C}$ 
density, viscosity, and heating value, indicate favorable changes as fuel candidates.

\section{Conclusions}

The fatty acid composition of non-edible vegetable oil affects on hydrocarbon product distribution. The higher saturation, the higher produced paraffins. Meanwhile, the higher unsaturation, the higher is cycloparaffin and alkyl benzenes produced. The presence of the carboxylic acid and oxygenated compounds indicates that the compounds have not completely converted to hydrocarbon compound at a temperature of $350{ }^{\circ} \mathrm{C}$. Therefore, the reactor temperatures over $350{ }^{\circ} \mathrm{C}$ were needed. In this work, aromatic compounds were only found in sunan candlenut liquid product. It means that polyunsaturated fatty acid in triglycerides in sunan candlenut oil can be converted to gasoil range hydrocarbon containing small amount of aromatics through hydrocracking reaction.

\section{Acknowledgement}

This work was supported by grant from Penelitian Dana Mandiri ITS. Authors are also appreciated to Muhammad Rizki Indra Saputra and Akhmad Ridho for their contribution during working in chemical reaction engineering laboratory, Department of Chemical Engineering, Institut Teknologi Sepuluh Nopember, Surabaya, East Java, Indonesia.

\section{References}

[1] Rabaev, M., Landau, M.V., Vidruk-Nehemya, R., Koukouliev, V., Zarchin, R., Herskowitz, M. (2015). Conversion of Vegetable Oils on $\mathrm{Pt} / \mathrm{Al}_{2} \mathrm{O}_{3} / \mathrm{SAPO}-11$ to Diesel and Jet Fuels Containing Aromatics. Fuel, 161: 287-294.

[2] Atabani, A.E., Silitonga, A.S., Ong, H.C., Mahlia, T.M.I., Masjuki, H.H., Badruddin, I. A., Fayaz, H. (2013). Non-Edible Vegetable Oils: A Critical Evaluation of Oil Extraction, Fatty Acid Compositions, Biodiesel Production, Characteristics, Engine Performance and Emissions Production. Renewable and Sustainable Energy Reviews, 18: 211-245.

[3] Gui, M.M., Lee, K.T., Bhatia, S. (2008). Feasibility of Edible Oil vs. Non-Edible Oil vs. Waste Edible Oil as Biodiesel Feedstock. Energy, 33: 1646-1653.

[4] Kim, S.K., Han, J.Y., Lee, H., Yum, T., Kim, Y., Kim, J. (2014). Production of Renewable Diesel via Catalytic Deoxygenation of Natural Triglycerides: Comprehensive Understanding of Reaction Intermediates and Hydrocarbons. Applied Energy, 116: 199-205.
[5] Pinto, F., Martins, M., Gonçalves, M., Costa, P., Gulyurtlu, I., Alves, A., Mendes, B. (2013) Hydrogenation of Rapeseed Oil for Production of Liquid Bio-Chemicals. Applied Energy, 102: $272-282$.

[6] Verma, D., Rana, B.S., Kumar, R., Sibi, M.G., Sinh, A.K.. (2015). Diesel and Aviation Kerosene with Desired Aromatics from Hydroprocessing of Jatropha Oil over Hydrogenation Catalysts Supported on Hierarchical Mesoporous SAPO-11. Applied Catalysis A: General, 490: 108-116.

[7] Marlinda, L., Al-Muttaqii, M., Roesyadi, A., Danawati, H.P. (2016). Production of Biofuel by Hydrocracking of Cerbera Manghas Oil Using Co-Ni/HZSM-5 Catalyst: Effect of Reaction Temperature. J. Pure App. Chem. Res., 5(3): 189-195.

[8] Al-Muttaqii, M., Marlinda, L., Roesyadi, A., Danawati, H.P. (2017) Co-Ni/HZSM-5 Catalyst for Hydrocracking of Sunan Candlenut Oil (Reutealis trisperma (Blanco) Airy Shaw) for Production of Biofuel. J. Pure App. Chem. Res., 6(2): 84-92.

[9] Santillan-Jimenez, E and Crocker, M. (2012). Catalytic Deoxygenation of Fatty Acids and their Derivatives to Hydrocarbon Fuels via Decarboxylation/Decarbonylation. J. Chem. Technol. Biotechnol., 87: 1041-1050.

[10] Veriansyah, B., Han, J.Y., Kim, S.K., Hong, S., Kim, Y.J., Lim, J.S., Shu, Y.W., Oh, S., Kim, J. (2012). Production of Renewable Diesel by Hydroprocessing of Soybean Oil: Effect of Catalysts. Fuel, 94: 578-585.

[11] Satyarthi, J.K. and Srinivas, D. (2011). Fourier Transform Infrared Spectroscopic Method for Monitoring Hydroprocessing of Vegetable Oils to Produce HydrocarbonBased Biofuel. Energy Fuels, 25: 3318-3322.

[12] Liu, C., Liu, J., Zhou, G., Tian, W., Rong, L. (2013). A Cleaner Process for Hydrocracking of Jatropha Oil into Green Diesel. Journal of the Taiwan Institute of Chemical Engineers, 44: 221-227.

[13] Marlinda, L., Al-Muttaqii, M., Gunardi, I., Roesyadi, A., Danawati, H.P. (2017). Hydrocracking of Cerbera manghas Oil with CoNi/HZSM-5 as Double Promoted Catalyst. Bulletin of Chemical Reaction Engineering \& Catalysis, 12(2): 167-184.

[14] Rismawati, R., Prihartantyo, A., Mahfud, M., Roesyadi, A. (2015). Hydrocracking of Calophyllum inophyllum Oil with Non-Sulfide CoMo Catalysts. Bulletin of Chemical Reaction Engineering \& Catalysis, 10(1): 61-69.

[15] Vitale, G., Molero, H., Hernandez, E., Aquino, S., Birss, V., Pereira-Almao, P. (2013). Onepot Preparation and Characterization of $\mathrm{Bi}$ - 
functional Ni-Containing ZSM-5 Catalyst. Applied Catalyst A : General, 452: 75-87.

[16] Zheng, X., Chang, J., Fu, Y. (2015). One-pot Catalytic Hydrocracking of Diesel Distillate and Residual Oil Fractions Obtained from Bio-Oil to Gasoline-Range Hydrocarbon Fuel. Fuel, 157: 107-114.

[17] García-Dávila, J., Ocaranza-Sánchez, E., Rojas-López, M., Muñoz-Arroyo, J.A., Ramírez, J., Martínez-Ayala, A.L. (2014). Jatropha curcas L. Oil Hydroconversion over Hydrodesulfurization Catalysts for Biofuel Production. Fuel, 135: 380-386.

[18] Kim, S.K., Brand, S., Lee, H., Kim, Y., Kim, J. (2013). Production of Renewable Diesel by Hydrotreatment of Soybean Oil: Effect of Reaction Parameters. Chemical Engineering Journal, 228: 114-123.
[19] Katikaneni S.P.R., Adjaye J.D., Bakhshi N.N. (1995). Catalytic Conversion of Canola Oil to Fuels and Chemicals over Various Cracking Catalysts. Can. J. Chem. Eng., 73: 484-497.

[20] Hancsók, J., Kasza, T., Kovács, S., Solymosi, P., Holló, A. (2012). Production of Bioparaffins by the Catalytic Hydrogenation of Natural Triglycerides. Journal of Cleaner Production, 34: 76-81.

[21] Da Rocha Filho, G.N., Brodzki, D., DjegaMariadasso, G. (1993). Formation of Alkanes, Alkylcycloalkanes, and Alkylbenzenes during the Catalytic Hydrocracking of Vegetable Oils. Fuel, 72: 543-549.

[22] Bayat, A., Sadrameli, S.M., Towfighi, J. (2016). Production of Green Aromatics via Catalytic Cracking of Canola Oil Methyl Ester (CME) Using HZSM-5 Catalyst with Different Si/Al Ratios. Fuel, 180: 244-255.

Selected and Revised Papers from The $2^{\text {nd }}$ International Seminar on Chemistry (ISoC 2016) (Surabaya, 26-27 July 2016) (http://chem.its.ac.id/isoc-2016/) after Peer-reviewed by Scientific Committee of ISoC 2016 and Peer-Reviewers of BCREC journal 